\title{
Pyonephrosis caused by Salmonella sp. in a patient with polycystic kidney disease undergoing hemodialysis
}

\author{
Pionefrose causada por Salmonella sp. em um paciente com \\ doença renal policística submetido a hemodiálise
}

Roberta Filipini Rampelotto', Talita Bertazzo ${ }^{2}$, Guilherme Lopes Weis ${ }^{3}$, Paulo Roberto O. de Jesus ${ }^{3}$, Mariane Vargas², Bettina Meneghetti ${ }^{4}$, Nara Lucia Dal Forno ${ }^{4}$, Adenilde Salla ${ }^{4}$, Rosmari Hörner ${ }^{1,2} \bowtie$

\footnotetext{
Postgraduate Program in Pharmaceutical Sciences, Universidade Federal de Santa Maria (UFSM). Santa Maria, RS, Brasil.

${ }^{2}$ Course of Pharmacy, UFSM. Santa Maria, RS, Brasil.

${ }^{3}$ Sector of Radiology, Hospital Universitário de Santa Maria (HUSM). Santa Maria, RS, Brasil.

${ }^{4}$ Laboratory of Clinical Analysis, HUSM. Santa Maria, RS, Brasil.
}

\section{ABSTRACT}

AIMS: This article reports a case of pyonephrosis caused by Salmonella sp. in a patient with polycystic kidney disease undergoing hemodialysis treatment.

CASE DESCRIPTION: An elderly male patient previously diagnosed with polycystic kidney disease undergoing standard hemodyalitic treatment presented uronephrosis, evolving to pyonephrosis caused by Salmonella sp., and was successfully treated with ciprofloxacin

CONCLUSIONS: The polycystic kidney disease may have contributed to the bacteria's attachment to the kidney, due to increase of permeability of the intestinal mucosa, easier bacterial translocation to bloodstream and its subsequent accommodation in the infected organ.

KEY WORDS: Salmonella infections; hydronephrosis; pyonephrosis.

\section{RESUMO}

OBJETIVOS: Este artigo relata um caso de pionefrose causada por Salmonella sp. em paciente com doença renal policística em tratamento por hemodiálise.

DESCRIÇÃO DO CASO: Um paciente idoso do sexo masculino, previamente diagnosticado com doença renal policística, em tratamento convencional por hemodiálise, apresentou uronefrose, evoluindo a pionefrose causada por Salmonella sp., sendo tratado com sucesso com ciprofloxacino.

CONCLUSÕES: A doença renal policística pode ter contribuído para a instalação da bactéria no rim, visto o aumento da permeabilidade da mucosa intestinal e maior facilidade de translocação da bactéria para a corrente sanguínea e seu posterior alojamento no órgão infectado.

DESCRITORES: infecções por Salmonella; hidronefrose; pionefrose. 
Abbreviation: PKD, polycystic kidney disease.

\section{INTRODUCTION}

Salmonella sp. is a gram-negative bacillus responsible for outbreaks of food-borne infections worldwide, as well as high rates of morbidity and mortality, especially in developing countries $[1,2]$. There is a great variety of Salmonella spp. serotypes pathogenic to human beings, the most common clinical disease being gastroenteritis $[1,3]$. Nevertheless, infections may occur in other sites out of the gastrointestinal tract, as well as may cause a septicemia [3]. Obstructions to urine drainage, like those caused by calculi, may lead to complications such as pyonephrosis, when urine becomes infected. In such cases the combination of prompt drainage associated with antibiotic therapy is imperative $[4,5]$.

This study aimed to report the isolation of Salmonella sp. from secretion drained from the surgical site of nephrostomy in a patient with chronic kidney disease admitted to a tertiary public hospital. The report was approved by the Research Ethics Committee of Universidade Federal de Santa Maria under the registration number 0285.0.243.000-09.

\section{CASE REPORT}

An 83-year-old male patient was admitted with a two month history of nausea, occasional vomiting, epigastric pain, prostration, fever, weight loss, lower limbs edema and oliguria. He was on chronic hemodialytic treatment, over the last three years, through an arteriovenous fistula in the left upper limb. His past medical history included chronic renal failure due to polycystic kidney disease (PKD), systemic arterial hypertension, benign prostatic hyperplasia, secondary hyperparathyroidism and an ischemic stroke two years before.

Laboratory workup revealed erythrocytes 3,21 million $/ \mathrm{mm}^{3}$; hemoglobin 9,6 g/dL; hematocrit 29,6\%; leucocytes $11900 \mathrm{~mm}^{3}$; neutrophils 84,4\%; high C-reactive protein levels, $58,67 \mathrm{mg} / \mathrm{dL}$ (reference value: $<0,3 \mathrm{mg} / \mathrm{dL}$ ), and blood creatinine $3,42 \mathrm{mg} / \mathrm{dL}$ (reference value for adult males: 0,8 to $1,2 \mathrm{mg} / \mathrm{ml}$ ). The urine test showed marked proteinuria and presence of blood with normal leukocytes and erythrocytes count; nitrite was absent and culture was negative.

A computed tomography showed marked dilation of the left pyelocalyceal system and ureter until the intramural urinary bladder segment, which was filled in by a dense fluid. Both kidneys presented exophytic cysts of varying sizes. The largest cyst measured $6.4 \mathrm{~cm}$ at its longest axis and had a thin wall (Figure 1). The patient was diagnosed with uronephrosis evolving to pyonephrosis, and was submitted to a nephrostomy. During the surgery, $30 \mathrm{ml}$ of purulent secretion were drained, from which Salmonella sp. was isolated. Blood cultures were negative.
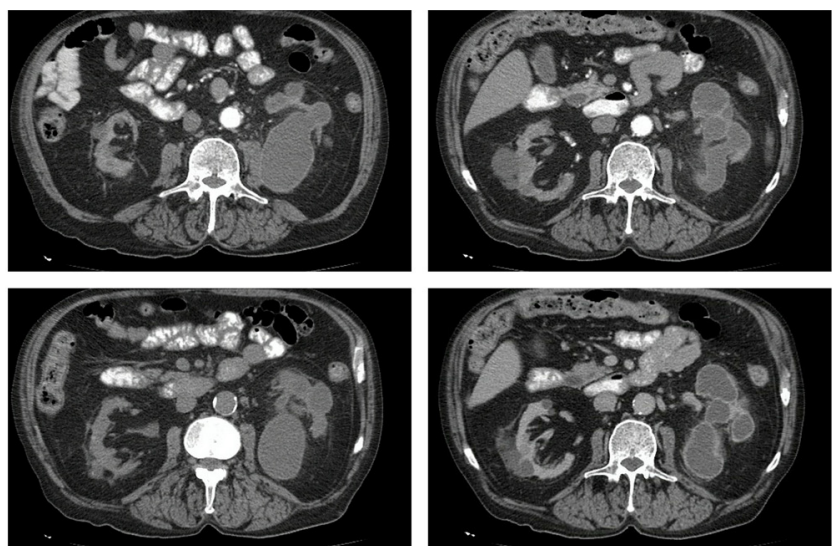

Figure 1. Computed tomography of the abdomen showing dilatation of the left pyelocalyceal system and ureter, and kidneys with exophytic cysts.

Antibacterial therapy with ceftriaxone was started. Antibiogram showed sensitivity to ampicillin, ampicillin/sulbactam, piperacillin/tazobactam, ceftazidime, ceftriaxone, cefepime, ertapenem, imipenem, meropenem, ciprofloxacin, tigecycline, and colistin, and resistance to cefuroxime, cefuroxime/axetil, amikacin, and gentamicin. Empiric antibiotic therapy with ceftriaxone was started and further replaced by ciprofloxacin after the sensitivity result. The patient was discharged six days after the nephrostomy and scheduled for 14 days of antibiotic therapy.

\section{DISCUSSION}

The genus Salmonella sp. may be divided into typhoid serotypes, which include Salmonella enterica var. typhi, Salmonella enterica var. paratyphi A, and hundreds of serotypes of non-typhoid Salmonella. The first group is responsible for typhoid fever and systemic infections, and the second is commonly associated to limited diarrheal episodes in developed countries, and septicemia in developing countries $[1,6]$. Infections involving Salmonella spp. in humans may present different clinical manifestations such as 
enteric fever, septicemia, focal disease (associated to bacteremia or not), gastroenteritis, and chronic carrier state [7]. Patients with gallbladder diseases are more prone to chronic colonization by this microorganism, which may remain in the reticuloendothelial system, from where it is continuously disseminated [1].

Complications resulting from infections in patients with PKD, especially those who are on chronic hemodialysis, are recurrent, tend to relapse and are life-threatening [8]. The cysts raise the intra-abdominal pressure and increase the permeability of the intestinal mucosa due to reduction of the blood flow in the microcirculation, therefore favouring bacterial passage through the intestinal wall $[9,10]$.

Patients who undergo hemodialysis are more prone to bacterial translocation, due to predisposing factors such as slow intestinal transit and heart failure [8]. The patient in this case was immunocompromised due to chronic kidney disease, a group of increased risk for this occurrence. Escherichia coli, Klebsiella spp., Proteus spp. and Pseudomonas spp. are frequently isolated from nephrostomy cultures, but Salmonella spp. are rarely found [1].

Due to virulence factors which enable multiresistance, the Clinical and Laboratory Standards Institute [11] advises that sensitivity tests should be performed for Salmonella spp. regarding the antimicrobials ciprofloxacin, levofloxacin, ofloxacin, pefloxacin, nalidixic acid, and azithromycin for S. typhi. In this report, the patient was treated with ciprofloxacin. However, there are reports of bacteria resistance to fluoroquinolones in developing countries. For this reason, treatment with third generation cephalosporins is an adequate alternative in these cases $[3,12]$.
A case similar to this was reported in 2011 , in a 40 years old male patient with autosomal dominant PKD, hospitalized with fever and flank pain after diarrhea. Salmonella enteritidis was isolated from coproculture and blood culture. Magnetic resonance and tomography identified kidney cysts, which were aspirated and from which the same microorganism was isolated, but no urinary obstruction was reported. The patient was successfully treated with ciprofloxacin. Those researchers supposed that bacterial translocation from the gastrointestinal tract caused bacteremia and may be responsible for infection of the renal cysts [13].

As the patient in this case report had PKD and was on chronic hemodialysis, we suppose that the infection was favoured by the bacterial translocation in a immunocompromised host. To the best of our knowledge, this is the first report of isolation of Salmonella sp. of pyonephrosis in the referred hospital.

\section{NOTES}

Acknowledgments

We gratefully acknowledge the pharmaceutical staff of the Laboratory of Clinical Analysis, Hospital Universitário de Santa Maria (HUSM)

\section{Financial support}

This study did not receive financial support from outside sources.

\section{Conflicts of interest disclosure}

The authors declare no competing interests relevant to the content of this study. They claim to have had full access to all available data and they take full responsibility for the integrity of the results described herein.

\section{REFERENCES}

1. Feasey NA, Dougan G, Kingsley RA, Heyderman RS, Gordon MA. Invasive non-typhoidal Salmonella disease: An emerging and neglected tropical disease in Africa. Lancet. 2012 June 30;379(9835):2489-99. https://doi.org/10.1016/S0140-6736(11)61752-2

2. Sood S. Breast Abscess by Salmonella Paratyphi A: Case Report and Literature Review. J Clin Diagn Res. 2015 Sept;9(9):DD03-4. https://doi.org/10.7860/jcdr/2015/15083.6539

3. Kaur A, Sarma S, Kumar N, Sengupta S. Renal Abscess Caused by Salmonella Typhi. J Lab Physicians. 2015 July-Dec;7(2):121-3. https://doi.org/10.4103/0974-2727.163132

4. Al-Qaoud T, Al-Terki A. A 42 Year Old Female with Pyonephrosis and Multiple Subcapsular Abscesses: Saving a Threatened Kidney. Clin Exp Med Sci. 2013;1(2):83-96. https://doi.org/10.12988/cems.2013.13008

5. Flukes S, Hayne D, Kuan M, Wallace M, McMillan K, Rukin NJ. Retrograde ureteric stent insertion in the management of infected obstructed kidneys. BJU Int. 2015 Apr;115 Suppl 5:31-4. https://doi.org/10.1111/bju.12918

6. Dandekar T, Fieselmann A, Fischer E, Popp J, Hensel M, Noster J. Salmonella-how a metabolic generalist adopts an intracellular lifestyle during infection. Front Cell Infect Microbiol. 2015 Jan 29;4:191. https://doi.org/10.3389/fcimb.2014.00191

7. Sudhaharan S, Padmaja K, Solanki R, Lakshmi V, Umabala P, Aparna B. Extra-intestinal Salmonellosis in a tertiary care hospital in South India. J Infect Dev Ctries. 2014 July 14;8(7):831-7. https://doi.org/10.3855/jidc.3731

8. Sabanis N, Paschou E, Gavriilaki E, Mourounoglou M, Vasileiou S. Unexpected Abscess Localization of the Anterior Abdominal Wall in an ADPKD Patient Undergoing Hemodialysis. Case Rep Nephrol. 2015;2015:982575. https://doi.org/10.1155/2015/982575 
9. Kaussen T, Srinivasan PK, Afify M, Herweg C, Tolba R, Conze J, Schachtrupp A. Influence of two different levels of intra-abdominal hypertension on bacterial translocation in a porcine model. Ann Intensive Care. 2012 July 5;2 Suppl 1:S17. https://doi.org/10.1186/21105820-2-S1-S17

10. Cheng J, Wei Z, Liu X, Li X, Yuan Z, Zheng J, Chen X, Xiao G, Li X. The role of intestinal mucosa injury induced by intra-abdominal hypertension in the development of abdominal compartment syndrome and multiple organ dysfunction syndrome. Crit Care. 2013 Dec 9;17(6):R283. https://doi.org/10.1186/cc13146

11. Clinical and Laboratory Standards Institute. Performance Standards for Antimicrobial Susceptibility Testing; Twenty-Fifth Informational Supplement. CLSI document M100-S25. Wayne PA: Clinical and Laboratory Standards Institute; 2015 [cited 2016 Aug 15]. Available from: http://shop.clsi.org/site/Sample_pdf/M100S25_sample.pdf

12. Tang HJ, Chao CM. Nontyphoidal Salmonella urinary tract infection among elderly patients. J Microbiol Immunol Infect. 2016 Feb;49(1):157-8. https://doi.org/10.1016/j.jmii.2015.03.006

13. Tsuchiya Y, Ubara Y, Suwabe T, Hoshino J, Sumida K, Hiramatsu R, Hasegawa E, Yamanouchi M, Hayami N, Marui Y, Sawa N, Takemoto F, Takaichi K. The renal cyst infection caused by Salmonella enteritidis in a patient with autosomal dominant polycystic kidney disease: how did this pathogen come into the renal cysts? Clin Exp Nephrol. 2011 Feb;15(1):151-3. https://doi.org/10.1007/ s10157-010-0364-2 